338.1

Un319ct

\title{
U.S.... Agricultural
}

adjustmerit administration

Commodity information series.

$$
\text { Tobacco leaflet. }
$$







\title{
UNITED STATES DEPARTMENT OF AGRICULTURE
}

\author{
AGRICULTURAL ADJUSTMENT WDMINISTRATION \\ WASIIINGTON, D. C.
}

\section{PURPOSES AND OPERATION OF THE KERR-SMITH TOBACCO ACT}

Whether the Kerr-Smith Tobacco Act will be made effective for flue-cured, Burley, fire-cured, or dark air-cured tobacco for the 1935 crop year will depend upon the outcome of a referendum among tobacco producers of each type of tobacco. The referendum is to be held in December.

The question which will be submitted to those eligible to vote in the referendum is:

"Do you favor a tax on the sale of tobacco for the crop year beginning May 1, 1935, as provided in the Kerr-Smith Act?"

The attitude of the Agricultural Adjustment Administration in the referendum is that of an impartial observer. If the Act is to be effective in 1935 for flue-cured, Burley, fire-cured, or dark air-cured tobacco, the persons who own, rent, share-crop, or control threefourths of the land customarily engaged in the production of each type of tobacco must favor its continuance. Growers of one type of tobacco may have the Act applied to their type even if growers of a different type should reject it.

The act was passed at the request of a large number of tobacco growers to supplement and not to supplant the voluntary acreage adjustment programs under the Agricultural Adjustment Act.

Secretary of Agriculture Henry A. Wallace, in a report to the Senate Committee on Agriculture and Forestry on the tobacco bill when it was pending in Congress in June 1934, included this statement:

"The demand for this type of legislation did not originate in the Department but, according to our understanding, came from the farmers. Tobacco growers from practically all regions have indicated to us their interest in this measure. Tobacco productioncontrol associations, or county tobacco committees, or county agents speaking for tobacco growers, in practically all of the southern tobacco-growing counties, have expressed their approval of this measure. Approximately 95 percent of all tobacco growers are participating in the programs designed to improve the economic situation of tobacco growers, and we are interested in any steps that may be taken to protect as fully as practical the position of these cooperating growers."

Eligible persons are being given an opportunity, after watching the Act in operation, to vote on whether they want it continued into $99630^{\circ}-34$ 
the 1935 season. The basis for the referendum is provided in the Act itself and is in line with the Agricultural Adjustment Administration's policy of having farmers make key decisions in the development of important programs.

Irrespective of the outcome of the referendum, the 1935 voluntary adjustment contracts which growers signed in 1934 may be continued in 1935 at the discretion of the Secretary of Agriculture. Tobacco producer's who were eligible to sign a 1934-35 contract will be given an opportunity to sign the contract and have it apply only for the 1935 season if the program is continued.

The Ker'r-Smith Act levies a tax of $331 / 3$ percent on the gross sale price of all types of tobacco to which it applies, unless the Secretary of Agriculture prescribes a lower rate, which may not be less than 25 percent.

Contracting growers of the types to which the Act is applicable receive nontransferable tax-payment warrants, expressed in pounds of tobacco, to cover the amount of tobacco which they are permitted to market under their contracts. The Act provides that the Secretary may, in addition, issue in any county, to growers who could not obtain an equitable allotment under a contract, further warrants covering an amount of tobacco of any type not in excess of 6 percent of the amount of such type covered by the warrants issued to contracting producer's in the county.

All applications for allotments of tax-payment warrants under this provision of the Act must be recommended by the county tobacco committee and approved by the county agent before the Secretary issues tax-payment warrants. Two-thirds of the amount to be allotted to noncontracting growers in each county under the 6-percent provision, must be in allotments of not more than 1,500 pounds each.

Believing that the declared policy of the Act would be best effectuated thereby and with a view to making the Act a protective and not a prohibitory nor compuisory measure, Secretary Wallace fixed the rate of the tax levied on the 1934 crop at 25 percent of the gross sales value. This was the lowest possible rate permitted under the Act. It was specified in the belief that such a tax would permit the noncontracting farmer to continue to produce tobacco and receive a return equal to what his return would have been without the improvement in tobacco $\mathrm{f}$-ices brought about by the adjustment program. In brief, the Ac: seeks to prevent the man on the outside from unduly profiting by his neighbor's reduction in production. 

UNIVERSITY OF ILLINOIS-URBANA

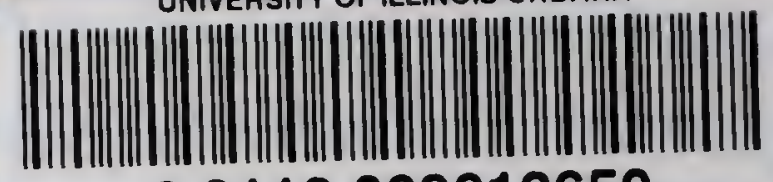

30112069612650 